\title{
Tradução
}





\title{
Discurso sobre os belos sentimentos ${ }^{1}$
}

\section{Gottfried Wilhelm von Leibniz}

\author{
Tradução de Oliver Tolle | Universidade de São Paulo
}

Os bons sentimentos são aqueles que tendem ao bem ou à virtude. E a alma é boa se esses sentimentos são predominantes.

Os grandes sentimentos são aqueles que permitem fazer qualquer coisa de grande. E a alma é grande quando ela está repleta deles.

Os belos sentimentos são aqueles que em tudo são bons e grandes. E a alma é bela quando ela é boa e grande ao mesmo tempo.

Há grandeza no mal; há também almas grandes entre os celerados, e Maquiavel observou que a causa da raridade das grandes ações se deve a haver poucos homens muito bons ou muito maus, isto é, porque há poucas almas grandes. Ao perder muitos de seus territórios, certo príncipe foi chamado de grande por seus bajuladores; mas conta a sátira que ele era como um buraco; quanto mais se tira, tanto maior o buraco se torna. É nesse sentido que o mal é grande.

O mal não é senão uma privação, tal como as trevas são privação de luz. Assim como o mal pode ser grande, também o bem pode ser pequeno ou medíocre. É o que ocorre com mais (maior) frequência. Eu já disse que o grande é raro em toda a parte. Mas por menor que seja o bem, ele pode ser suficiente, desde que seja proporcional aos nossos talentos e às nossas forças. Há duas

1 Discours sur les beaux sentiments. Seguimos aqui a versão contida na edição de Jean Baruzi, Leibniz - avec de nombreux textes inédits; Paris: Librairie Bloud, 1909, Pp. 365-369. Gostaria de agradecer especialmente a Marcos Ribeiro Balieiro pelas valiosas sugestões. 
maneiras de avaliar as coisas: o que é absolutamente pequeno se torna, comparativamente, de tamanho considerável. E ainda que a alma tenha nascido para coisas pequenas, ela é louvável quando encontra um dever.

Os talentos são as nossas forças internas. O que se chama costumeiramente de nossas forças é o talento das coisas exteriores, sobre as quais Deus nos confiou o governo.

A alma pode ser grande, quando as forças internas forem grandes, ainda que os bens externos não sejam correspondentes.

As forças internas ou forças da alma são de dois tipos: naturais ou adquiridas. A natureza nos forma, a arte nos completa.

Aqueles que na educação das crianças deixam tudo a cargo da natureza não consideraram suficientemente a natureza. Eles devem observar os caçadores, os estribeiros e aqueles que comandam os cavalos, os cães e os pássaros; devem observar os jardineiros em seu trabalho e como cortam e endireitam as árvores.

É verdade que não está em nosso poder aumentar as forças que a natureza produziu. E, não obstante, a arte pode nos dar forças que a natureza recusou.

Como conciliar essas duas verdades opostas? É que a arte reúne e emprega as forças que a natureza mantém dispersas e desviadas. Ao reunir riachos em um canal, recolhe-se água suficiente para mover moinhos ou para transportar barcos. Um espelho côncavo se aquece ao reunir os raios do sol que foram dispersos pelo ar.

O mesmo se passa com as forças da alma. Por natureza, o nosso espírito é dissipado, e desde a infância somos entretidos por milhares de bagatelas que dividem a nossa atenção. A arte não faz outra coisa senão reunir e dirigir os nossos pensamentos.

Veja como a criança corre em direção ao primeiro objeto. Ela é atraída por um sapo, por uma borboleta. Somos semelhantes às borboletas que voam em torno do fogo e acabam se queimando. A maioria dos homens são como crianças durante toda a sua vida; eles gostam de correr atrás de bagatelas. Devemos ter apenas um 
imã que nos atrai e nos confere direção. Esse imã é a verdadeira felicidade. Mas temos inúmeros imãs, que nos fazem mudar.

Os divertimentos nos desviam do verdadeiro caminho e nos fazem perder o tempo da corrida: como naquela fábula da Atalanta, que parou para pegar as maçãs de ouro jogadas pelo corredor com o objetivo de pará-la, o que custou sua felicidade. ${ }^{2}$

Vemos pessoas sérias assemelharem-se ao gato de Esopo. Júpiter transformou um gato em menina para agradar um jovem que amava a distração e que não deixou de se casar com a menina. Ela estava lindamente vestida no dia do seu casamento e manteve tanta seriedade quanto podia. Mas casualmente apareceu um rato. Esse objeto acabou com toda a sua seriedade. As vestimentas, as louças, tudo foi derrubado e destruído enquanto corria atrás do rato. Essa é a imagem dos homens que não têm força de espírito suficiente. Qualquer oferta de diversão os leva a negligenciar os assuntos mais importantes.

2 Referência à fábula "Corrida da Atalanta", Apolodoro III, 9.2. 

Resumos | Abstracts 



\section{$\mathrm{O}$ acordo afetivo da multidão: $\mathrm{O}$ desejo (desiderium) de vingança como princípio do corpo político}

Chantal Jaquet

Resumo: No Tratado político, VI, 1, Espinosa sustenta que o acordo da multidão que preside a constituição do corpo político não se funda sobre a razão, mas sobre um afeto comum: medo, esperança ou desejo de vingar um dano sofrido em comum (vel desiderio commune aliquod damnum ulciscendi). O objetivo deste artigo é analisar a possibilidade, a viabilidade e a legitimidade de uma união paradoxal e problemática da multidão com base em uma aspiração à vingança. A hipótese de um motor vingativo na origem do corpo político jamais foi objeto de um exame por parte dos comentadores, que se interessaram mais pelo temor, esperança ou indignação, negligenciando o desejo de vingança, embora expressamente mencionado por Espinosa. A reflexão visa então a destacar a originalidade desta tese, que tira o Estado do modelo contratualista para revelar sua natureza conspiratória, operando notadamente uma confrontação com Locke e distinguindo justiça e vingança. Trata-se, em seguida, de analisar os problemas que ela levanta, como a ausência de perenidade ou o risco de tirania ligados ao excesso de violência, e de interrogar-se sobre sua legitimidade e seu bom fondamento. Trata-se, enfim, de definir um bom uso da vingança, tomando o cuidado de distinguir, como o faz Espinosa, o desiderium de vingança e a cupiditas, e explicando a natureza exata do afeto vingativo sobre o qual o acordo da multidão pode legitimamente apoiar-se para definir um direito soberano e uma justiça comum.

Palavras-chave: Espinosa, Locke, Desejo, Cupiditas, Desiderium, Vingança, Medo, Esperança, Corpo Político, Estado.

L'accord affectif de la multitude: le désir (desiderium) de vengeance comme principe du corps politique

Resumé: Dans le Traité politique VI, 1, Spinoza soutient que l'accord de la multitude qui préside à la constitution du corps politique n'est pas fondé sur la raison mais sur un affect commun, crainte, espoir ou désir de venger un dommage subi en commun (vel desiderio commune aliquod damnum ulciscendi). L'objectif est d'analyser la possibilité, la viabilité et la légitimité d'une union paradoxale et problématique de la multitude sur 
la base d'une aspiration à la vindicte. L'hypothèse d'un motif vindicatif à l'origine du corps politique n'a jamais fait l'objet d'un examen de la part des commentateurs qui se sont intéressé plutôt à la crainte, à l'espoir ou à l'indignation, en négligeant le désir de vengeance pourtant expressément mentionné par Spinoza. La réflexion vise alors à dégager l'originalité de cette thèse, qui arrache l'Etat au modèle contractuel pour en révéler la nature conspiratrice, en opérant notamment une confrontation avec Locke et en distinguant justice et vengeance. Il s'agit ensuite d'analyser les problèmes qu'elle soulève, comme l'absence de pérennité ou le risque de tyrannie liés à la surenchère de violence et de s'interroger sur sa légitimité et son bien-fondé. Il s'agit enfin de définir un bon usage de la vengeance en prenant soin de distinguer, comme le fait Spinoza, le desiderium de vengeance de la cupiditas et en explicitant la nature exacte de l'affect vindicatif sur lequel l'accord de la multitude peut légitimement prendre appui pour définir un droit souverain et une justice commune.

Mots-clés: Spinoza, Locke, Désir, Cupiditas, Desiderium, Vengeance, Crainte, Espoir, Corps Politique, État.

\section{De Lípsio a Espinosa. Do horizonte da guerra à paz}

Resumo: O texto busca reconstruir o debate acerca da guerra e da paz a partir das reflexões empreendidas desde o final do século XVI. Partindo de Lípsio e lançando mão da abordagem de autores fundamentais do século XVII, apresenta-se o ambiente intelectual e as afinidades e oposições de Espinosa em relação a ele.

Palavras-chave: Filosofia Política, Guerra, Paz, Lípsio, Espinosa.

\section{From Lipse to Spinoza. From the war horizon to the peace}

Abstract: The paper aims at the reconstruction of the debate of war and peace through the enquiries undertaken at the end of the 16 th and the course of the 17 th centuries. Beginning with Lipse, the text approaches the most fundamental intellectual theories in the context of Spinoza's thesis on this subject.

Keywords: Political Philosophy, War, Peace, Lipse, Spinoza. 


\section{Quién más ama las cosas. Radicalismo democrático y libertad igualitaria en Francis van den Enden}

Diego Tatián

Resumo: Este artigo busca apresentar as teses de Francis van den Enden acentuando-se as origens de uma questão muito cara a Espinosa, a da liberdade. Destacando a presença oculta do primeiro no último, apresenta-se as bases do pensamento político do último Espinosa. Palavras-chave: Liberdade, Democracia, Igualdade, Espinosa, Francis van den Enden.

Those who loves the things at most. Democratic radicalism and equal freedom in Francis van den Enden

Abstract: The article presents the major thesis of Francis van den Enden and points to the origins of a very important matter to Spinoza, that is to say, freedom. Bringing into light passages where we can detect the influence of the former in the Political Treatise, the text shows the basis of the thinking of the late Spinoza in its historical context.

Abstract: Freedom, Democracy, Equality, Spinoza, Francis van den Enden.

\section{A dialética de república e democracia no jovem Marx, entre Espinosa e Rousseau}

Vittorio Morfino

Resumo: Buscando uma alternativa à já célebre oposição ao pensamento político de Hegel no jovem Marx, o texto apresenta uma outra genealogia possível às obras de juventude do autor de Grundrisse. Essa genealogia o ligaria a dois pensadores que se tornariam fundamentais à história do pensamento político, Rousseau e Espinosa. Palavras-chave: Marx, Rousseau, Espinosa, Teoria Política.

The republican and democratic dialectics in young Marx, between Spinoza and Rousseau

Abstract: Searching for another way of approaching the young Marx, beyond the well known opposition to the hegelian political thinking, the text points to an alternative genealogy to the early works of Marx. This genealogy links his theories with two fundamental thinkers of politics, 
Rousseau and Spinoza.

Keywords: Marx, Rousseau, Espinosa, Political Theory.

\section{Espinosa, Kelsen e a natureza da norma jurídica}

Diogo Pires Aurélio

Resumo: O artigo busca colocar a relação pouco estudada da obra de Kelsen com Espinosa. Traçando afinidades, oposições e apropriações, as obras do vienense, ainda que muito distantes no tempo das do filósofo holandês, apresentam questões presentes no pensamento político espinosano. Entre elas, o eco do imperium de Espinosa no Estado kelseniano.

Palavras-chave: Espinosa, Kelsen, Teoria do Estado.

Spinoza, Kelsen and the nature of the juridical norm

Abstract: The paper aims at the understudied relationship of Kelsen's work and Spinoza theory. Tracing affinities, oppositions and appropriations, the central works of Kelsen, even still the great distance in time, present questions that have its origins in the political thought of Spinoza. As the clear link between the spinozian notion of imperium and the kelsenian State.

Keywords: Spinoza, Kelsen, Theory of State.

\section{Quentin Skinner e a liberdade republicana em Maquiavel}

Alberto Ribeiro G. de Barros

Resumo: A intenção deste artigo é discutir a concepção de liberdade encontrada nos escritos políticos de Maquiavel com base na interpretação feita por Quentin Skinner. Esta interpretação tem sido geralmente aceita por teóricos do chamado neorrepublicanismo, como Philip Pettit e Maurizio Viroli, sustentando suas ideias sobre a liberdade republicana. Não se trata assim de uma discussão meramente hermenêutica, mas de uma contraposição a uma interpretação parcial que, ao enfatizar o aspecto legal da concepção maquiaveliana, ampara uma perspectiva fortemente jurídica da liberdade republicana. O texto está dividido em três partes: a primeira apresenta as razões pelas quais a concepção maquiaveliana foi retomada por Skinner; a segunda expõe a 
sua interpretação; e a terceira problematiza aspectos desta interpretação com base em características fundamentais do pensamento político de Maquiavel que devem ser consideradas na avaliação de sua concepção de liberdade.

Palavras-chave: Liberdade, Republicanismo, Maquiavel, Skinner.

\section{Quentin Skinner and the republican freedom in Machiavelli}

Abstract: My purpose is to discuss the conception of liberty found in Machiavelli's political writings based on Quentin Skinner's interpretation. This is because some republican authors such as Philip Pettit and Maurizio Viroli have been accepted his interpretation, holding their legal perspective of republican liberty. Then, it is not only a hermeneutic discussion, but also an opposition to a partial interpretation that emphasize the legal aspect of Machiavellian conception. My paper is divided into three parts: the first presents the reasons why Skinner took up the Machiavellian conception; the second sets out his interpretation; and the third quarrels aspects of his interpretation based on key features of Machiavelli's political thought that should be considered in this discussion.

Key Words: Liberty, Republicanism, Machiavelli, Skinner.

\section{Em direção ao núcleo da 'obra Maquiavel': sobre a divisão civil e suas interpretações}

Resumo: O texto apresenta a construção contemporânea do Maquiavel republicano partindo das três clássicas leituras de Maquiavel, a saber, a de Lefort, Pocock e Skinner, sem deixar de lado o confronto com os próprios textos do autor de O Princípe. Enquanto o primeiro acentuava no autor fiorentino uma ruptura com a filosofia política clássica, os dois últimos estabeleceram nele o elo central da tradição republicana. O tema da divisão civil, de diversidade interpretativa inconteste, é recolocado na esteira desses consagrados comentários da obra de Maquiavel.

Palavras-chave: Maquiavel, Lefort, Pocock, Skinner, Divisão Civil, Republicanismo.

Towards the core of the 'Machiavelli work': about the civil division and its interpretations 
Abstract: The text presents the contemporary construction of the republican Machiavelli, through the classical commentaries of Lefort, Pocock and Skinner, as well as the confontation with the own works of the Florentine author.

Keywords: Machiavelli, Lefort, Pocock, Skinner, Civil Division, Republicanism.

\section{Causalidade e necessidade na ontologia de Espinosa}

Resumo: Este trabalho pretende reconstruir a cadeia demonstrativa do livro I da Ética de Espinosa do ponto de vista de sua concepção de causalidade. Presente desde a primeira definição da obra (a causa sui), a noção de causa vai determinar toda a ontologia de Espinosa, levando à negação completa da contingência e, consequentemente, à afirmação da realidade como absolutamente necessária.

Palavras-chave: Espinosa, Causalidade, Necessidade, Ontologia.

\section{Causality and necessity in Spinoza's ontology}

Abstract: This paper intends to reconstruct the demonstrative chain presented in the first book of Spinoza's Ethics in the perspective of his conception of causality. Present since the first definition of the work (the causa sui), the notion of cause will determinate all of Spinoza's ontology, leading to the complete refusal of contingency and consequently to the affirmation of reality as absolutely necessary.

Key-words: Spinoza, Causality, Necessity, Ontology.

\section{Leyendo a Claude Lefort: tras el rastro de Leo Strauss}

Resumo: O artigo busca perseguir o diálogo explícito e implícito de Lefort com a obra de Leo Strauss, dando conta dos pontos de consenso e dissenso. Partindo das célebres obras desses autores sobre Maquiavel, o que se pretende mostrar é a figura de Strauss como interlocutor privilegiado nos interesses de Lefort e os seus diversos pontos de intersecção. 
Palavras-chave: Claude Lefort, Leo Strauss, Política, Democracia.

\section{Reading Claude Lefort: following the footprints of Leo Strauss}

Abstract: This paper focuses on the dialogue explicit and implicit established by Lefort with the works of Leo Strauss, regarding their aspects of agreement and disagreement. To show how Strauss is a consolidated interlocutor of Lefort, the text follows their classical works on Machiavelli as a starting point and the subsequently intersections in both theories.

Keywords: Claude Lefort, Leo Strauss, Politics, Democracy.

\section{O Estado: segurança e insegurança}

Resumo: O texto faz uma anatomia das reflexões modernas acerca do Estado e de seus problemas a partir da emergência do Estado liberal enquanto modelo. A partir da ideia neoliberal de redução de ação estatal, o seu suposto enfraquecimento é identificado como um dos móbiles de seu fortalecimento. Empreende-se, então, um comparativo rigoroso das condições políticas do século XIX com as do final do século $\mathrm{XX}$ até nossos dias, no qual ressaltam-se as fissuras do discurso liberal contemporâneo.

Palavras-chave: Teoria do Estado, Liberalismo, Ação Estatal.

\section{The State: security and insecurity}

Abstract: The article brings up an anatomy of the modern theories of State and its problems through the rising of the liberal way of thinking it. From the neoliberal aspect of State reduction, the supposed undermining is identified as one of the mottos of its empowerment.

Keywords: State Theory, Liberalism, State Action. 
Projeto gráfico e imagem da capa Marcelo Girard

Diagramação $\mathrm{IMG}_{3}$ 